\title{
Relationship between Corporate Capital Structure and Stocks Liquidity: Empirical Evidence in Vietnam
}

\author{
Vu Thi Thuy Van (Corresponding author) \\ School of Banking \& Finance, National Economics University, Ha Noi, Viet Nam \\ E-mail: thuyvan@neu.edu.vn
}

Tran Thi Thoa

School of Banking \& Finance, National Economics University, Ha Noi, Viet Nam

E-mail: thoa97at@gmail.com

Ngo Thanh Xuan

School of Banking \& Finance, National Economics University, Ha Noi, Viet Nam

E-mail: xuantn@neu.edu.vn

Nguyen Nhat Linh

School of Banking \& Finance, National Economics University, Ha Noi, Viet Nam E-mail: nhatlinhkss.nhtc@neu.edu.vn

Received: Sep. 29, 2018 Accepted: Nov. 26, $2018 \quad$ Published: December 1, 2018

doi:10.5296/ajfa.v10i2.13719 URL: https://doi.org/10.5296/ajfa.v10i2.13719

\begin{abstract}
The paper examines the impact of capital structure on the liquidity of listed shares on the Ho Chi Minh City Stock Exchange, which includes 1078 observations during the period of 2011 - 2017. In addition to the capital structure, the study also looked at the impact of controlled variables including profitability (ROS), corporate value (Tobin's Q) and size of the business (SIZE) on the liquidity of listed shares. The results show that the capital structure has
\end{abstract}




\section{Macrothink}

Asian Journal of Finance \& Accounting ISSN 1946-052X

inherently inverse relationship, while the controlled variables in the model have a positive relationship with stocks' liquidity.

Keywords: Capital Structure, Liquidity, Corporate Value, Stock Market, Financial Leverage 


\section{Introduction}

For a business, liquidity is the top priority, because it is the status, prestige, the power of a business. The stock's liquidity is good when the stock is easy to trade on the market, attracting investors to invest in to find profitable investment opportunities, helping the business mobilize large capitals. Conversely, if the stock of a business is less liquid, the business will suffer negative impact on the performance, resulting in the sale of investment projects, assets, capital mobilization with high fees and the worst scenario is bankruptcy.

Over the past ten years, the financial market in Vietnam has grown exponentially but also contains many inherent risks depending on the fluctuation of the macro economy and the enterprises themselves. On the stock market, the risk of stock liquidity is increasing with more complex trends. One of the fundamental reasons is that financial management in many businesses is not respected. Facing the opportunities and challenges of the economic reform process, the efficient use of resources for development, including capital resources, needs to be paid more attention by businesses.

Many empirical studies in the world and Vietnam have examined the relationship between capital structure and liquidity of stocks. However, past researches have not yet clarified the effect of capital structure on stock liquidity but mainly focused on studying the effect of stock liquidity on capital structure decision.

Based on the above reasons, the authors decided to select the topic "Relationship between corporate capital structure and stock liquidity: empirical evidence in Vietnam".

\section{Theoretical Background}

\subsection{Some theories concerning the corporate capital structure and stock liquidity}

\subsubsection{Theories of capital structure}

Trade-offs theory of capital structure: The theory of modern capitalism derives from Modigliani and Miller (1958). The main hypothesis of the study is that the value of a company is independent from its capital structure. In 1963, they changed their theory by adding tax elements to their original research. With the presence of corporate income tax, M\&M claims that the use of debt will increase the value of a business. However, businesses cannot fully finance their business with debt. Although, benefiting from the tax shield, debt financing generates expenses, especially cost of financial exhaustion (including bankruptcy costs and financial exhaustion but not bankruptcy). As the result, businesses are always looking to optimize the total value of the business based on the equilibrium principle to determine how much debt financing and how much equity capital to allocate in their capital structure. The theory of capital structure swap balances the advantages of debt and financial exhaustion.

Agency cost theory: The agency cost theory is further developed in the study of Jensen \& Meckling (1976) and Jensen (1986). This theory is derived from the conflict of interest between the Board of Directors and the shareholders. Agency cost is the cost incurred by the owner of the firm when there is a separation between ownership and management rights. In a 
business, the distinction between ownership and management is essential. However, this delimitation will create many complex issues related to the interests of the parties. Shareholders always want to maximize the value of their business and the value of their equity. On the other hand, managers tend to invest in projects that increase the size of the business. This type of decision is solely based on their judgement and contains many risk factors, however, does not increase shareholders' interest. Jenshen and Meckling argue that there are two types of contradictory conflicts: the conflict between shareholders and business managers and the conflict between shareholders and creditors. This basic contradiction has created an agency cost. The agency cost usually reduced the benefit of using the debt as financial support. The agency cost theory presents that an optimal capital structure can be achieved by balancing the agency cost with the benefit of using debt.

Classification theory: Classification theory developed by researcher Myers and Majluf(1984). This theory explains the company's funding decisions based on asymmetric information. The basic concept of asymmetric information proposed a prioritized financing order, in which profits should be kept to reinvest into the business first (retained earnings), followed by debt issuance and eventually capital issuance or new shares. The issuance of new equity is usually the last resort when the company has exhausted its ability to borrow. This theory helps explain why companies with high profitability tend to have lower borrowing ratios than others because they have more internal capital to finance themselves; whereas low-profit firmstend to issue debt because they do not have enough internal capital for their investment projects. Debt issuance is topped in the ranking order of external funding.

\subsubsection{The theory of stock liquidity}

The liquidity of a stock has many different definitions but can be understood simply by the quicklinessof buying or reselling a stock without losing its value. There are many different concepts raised by researchers and professional investors. Robert F. Stambaugh (2002) introduced the concept of stock liquidity as follows: "Stock liquidity is a very broad and unclear concept, but generally, it reflects the ability to trade a large volume of stock quickly at a low cost with little price fluctuation." Wasfi A. Al Salamat (2016) argues that it is difficult to give an explanation of stock liquidity and suggests the following: "It (stock liquidity) is the ability of investors to buy or sell a large amount of stock at ease and without significant loss."

Stock liquidity has not only one but also many different characteristics. The liquidity of the stock is based on the following four fundamental characteristics:

- "Transaction time: is the execution of an immediate transaction at a common price. Timeout between two transactions and the number of transactions in a time unit are measure of the transaction time.

- Tensions: the ability to buy or sell a certain amount of stock at an equal price at the same time. Expenses related to the transaction or the cost of waiting express the tightness.

Tensile measures are the different types of price differences. 
- Depth: the ability to buy or sell a certain amount of stock without affecting the listed price. Listed price is the ask or bid price placed in the order book. A sign of weak liquidity is resulted from the negative impact of the market on investors when trading. The depth of the market can be measured by the order index, transaction volume or cash flow index.

- $\quad$ Elasticity: the ability to buy or sell a certain amount of stock with little effect on price. When the depth of market is only concerned with the number of transactions at the best bid or ask price, the elasticity property assumes the elasticity of supply and demand. The degree of elasticity of liquidity is described by the income of the day".

\subsection{Some concepts}

\subsubsection{The concept of capital structure}

The capital structure of an enterprise is defined as the combination of debt and equity in the total long-term capital that an enterprise can mobilize to finance its investment projects. The term financial leverage implies the capital structure of an enterprise. Financial leverage is used to assess the extent to which a business finances its operations by borrowing.

Within the scope of the study, the authors used the debt-to-asset ratio and the debt-to-equity ratio as variables representing the financial leverage.

\subsubsection{Measure the stock liquidity}

Liquidity is a broad definition with many different dimensions that cannot be covered by a single metric. In this study, the authors use two different measures, including a liquidity metric and an inadequate measure of liquidity, to increase the validity of the study. These measures are widely used in the studies of scholars around the world. The computation of these two measures is as follows:

- Method of measurement using stock turnover (Turnover)

$$
\text { Turnover }=\frac{\text { Annual Sales }}{\text { Total Annual Share Outstanding on Average }}
$$

This method merely performs a business measurement of trading volume over a one-year period compared to the number of shares outstanding at the end of the previous year in order to reflect the liquidity of listed shares on the market more precisely, because the number of outstanding shares in circulation can change over time. Therefore, an individual investor is most likely to be interested in this method of measurement.

- The method of measuring the frequency of the zero-yielding day (Zeros)

This low liquidity measurement was developed by Lesmond, Ogden and Trzcinka (1999), which is calculated as follows:

$$
\text { Zeros }=\frac{\text { Numbers of Trading Days with } 0 \text { Return in Year } t}{\text { Total Numbers of Trading Days in Yeart }}
$$


If the company has a high transaction cost, it will be a negative influence on stock trading, creating a barrier to the investors making their transactions and forcing them to exploit their own information. As the result, more shares with less liquidity will be traded on days with 0 return.

Investors in the market are unpredictable. The number of investors fluctuate frequently and directly affect the efficiency of business operations. Therefore, strategic managers need to update information on this issue in order to have appropriate business strategies and to effectively deal with problems that may incur.

\section{Research Overview}

\subsection{Research overview on liquidity measures}

Liquidity is an abstract concept, with many different definitions by researchers and professional investors. In the simplest sense, liquidity is the easy level of trading a certain stock. Previous research focused on developing liquidity measures from developed to emerging markets. There are a number of measures taken to choose how to measure the liquidity of a stock from a variety of perspectives and different liquidity concepts. Typically, Amihud (2002) measured liquidity by price sensitivity, Lesmond et al. (1999) measured liquidity based on the frequency of the zero-yielding day, or Roll (1984) measured liquidity based on ask or bid price. Liquidity is a broad definition with many different aspects that only one measure cannot cover the whole. Domestic writings of authors such as Le Dat Chi and Hoang Thi Phuong Thao (2015) used six liquidity metrics as the relative price difference, stock turnover, sensitivity measure of price, the frequency of the zero-yielding day, the implied market spread, and the depth of the market to reinforce the research on "The impact of the global financial crisis on the liquidity of Vietnamese securities".

\subsection{Results of empirical research on the relationship between capital structure and stock liquidity}

There are a lot of studies on the relationship between capital structure and liquidity of stocks. The first is a study of the interplay of stock liquidity and capital structure of firms listed on the NYSE in 1988-1998 by Frieder and Martell (2006). Hypothetical test results show that high leverage increases liquidity, which is consistent with the idea that debt managers must make better investment decisions (Jensen, 1986), thereby reducing agency costs between managers and investors, and increasing the liquidity of the stock (Kyle, 1985). On the other hand, the results also show that any decline in stock liquidity increases financial leverage. Udomsirikul and Fortune (2011) conducted a study on the relationship between capital structure and stock liquidity on 707 companies in Thailand in the period of 2002-2008. The authors use three liquidity measures including method by Amihud (2002), modified turnover, and adjustable liquidity ratios, which represents the liquidity of the stock and the debt-to-asset ratio represents the capital structure. Thailand is a less complex capital market than the United States with predominant bank loans and more centralized corporate ownership. In spite of these differences, the author's study gives the result of the negative correlation between stock liquidity and financial leverage. Lesmond, O'Connor and Senbet 
(2008) studied capital structure and stock liquidity with 226 non-financial companies from 1980-2006. Data sets are collected from financial reports and the Dow Jones index. Using three liquidity measures, one estimates the price effect based on the Hasbrouck (2007) model, Lesmond et al. (1999), and the purchase price difference (representing the cost of instantaneous), the authors found that increased financial leverage was associated with reducing stock liquidity and decreased financial leverage related to increasing stock liquidity.

Rasa Norvaišienė and Jurgita Stankevičiene (2014) reviewed the impact of the company specific factors on stock liquidity on the Baltic stock market between 2005 and 2012. Factors of the company included in the study are such as the business size, ROA, financial leverage (measured by debt to equity), profit or loss ratio, current solvency. The study showed that the higher the equity of Estonia's companies, the higher the liquidity affected by the increase in financial leverage. Stock liquidity of Latvian companies during 2005-2012 is affected only by the size of the companies. The liquidity of the Lithuanian companies' shares during the research period was positively influenced by the size of the companies and the return on their assets. However, financial leverage has a negative impact on stock liquidity. Wasfi A. Al Salamat (2016) studied the effects of factors in the macro-economy and the company's unique factors on stock liquidity - empirical evidence from Jordan showed that stock liquidity is positively influenced by financial leverage, earnings per share (EPS), interest rates, gross domestic product (GDP), and size; whereas it is negatively influenced by market price-to-book ratio and return-on-asset (ROA).

In Vietnam, the study of Dang Thi Phuong (2012) with the theme of "Liquidity of stocks and capital structure of listed companies on Ho Chi Minh City Stock Exchange" with the data of 60 companies listed on the Ho Chi Minh Stock Exchange between 2006-2011.Correlation coefficient analysis and multiple linear regression models were used to test the hypothesis. The results of the study also showed the opposite relationship between financial leverage representing corporate capital structure and stock liquidity. In addition, the study found five factors (among the six factors outside the liquidity factor studied) that have an impact on capital structure including growth opportunities, firm size, depreciation rates(having positive relationship with financial leverage), the rate of return and stock market price (having negative relationship with financial leverage). The group of authors Vo Xuan Vinh, Tran Thi Yen Duyen (2015) also studied the above topic but with a broader scope when conducting research on the stock market of Vietnam from 2006 to 2012. With the Pooled OLS regression analysis, the results showed that the liquidity of the stock is positively related to the company's capital structure.

\section{Modeling and Research Methodology}

\subsection{Research hypothesis}

Capital structure: Capital structure (financial leverage) is an important factor affecting the liquidity of stocks. Theoretical and empirical studies by Udomsirikul et al. (2011), Lesmond et al. (2008), RasaNorvaišienė and JurgitaStankevičienè (2014), Dang Thi Phuong (2012), Vo Xuan Vinh, Tran Thi Yen Duyen (2015)showed that the capital structure is inversely related to stock liquidity. However, according to the study by Frieder and Martell (2006), Wasfi A. 
Al Salamat (2016), there is positive relationship between capital structure and stock liquidity. The proposed research hypothesis is as follows:

$H_{1}$ : Financial leverage is inversely related and statistically significant to stock liquidity.

Business scale: For investors, they are more likely to be interested in large-scale businesses, where information is more transparent, clear to the public so that they can capture accurate information and have rapid access to information streams to make appropriate investment decisions. As the result, more trading activities will occur to help create more market liquidity. In addition, shares of large-scale enterprises can be traded easier, faster and without significant devaluation compared to stocks of small and medium enterprises. The results of these studies are consistent with the above-mentioned theoretical basis, showing that the size of the business is closely related to stock liquidity (RasaNorvaišienè and JurgitaStankevičienè, 2014; Wasfi A. Al Salamat, 2016; Sedeaq Nassar, 2016). Based on these studies, we have the following hypothesize:

\section{$\mathrm{H}_{2}$ : The size of the business has positive and significant impact on stock liquidity}

Corporate profitability: Examining the effect of profitability on liquidity of stock, studies by Hansen, S., \& SungSuk, K. (2013), Rasa Norvaišienè and Jurgita Stankevičienè (2014), Sedeaq Nassar (2016) showed a positive relationship between stock liquidity and corporate value. This can be explained by the fact that if a business has good business results and high profitability, then stocks with high returns will attract investors to exploit profit opportunities and thus increase the liquidity of the stock. The proposed research hypothesis is as follows:

\section{$H_{3}$ : The profitability of the business has positive and significant impact on stock liquidity}

Corporate value:A good business or high corporate value is usually traded at a better price (Allayannis \& Weston, 2001). Moreover, the high value enterprise will attract investment. The study by Trang Nguyen, Duong Huu Nhan, Harminder Singh (2016) also makes the same conclusion. Therefore, corporate value is also considered as an important factor influencing the liquidity of stocks. The proposed research hypothesis is as follows:

$H_{4}$ : The corporate value has positive and significant impact on stock liquidity

\subsection{Model and research data}

Based on a review of the impact of capital structure on stock liquidity and research hypotheses, the regression model proposed in the study to test the hypotheses is as follows:

$$
\begin{aligned}
& \text { Model 1: } \mathrm{TO}_{\mathrm{it}}=\beta_{0}+\beta_{1} \mathrm{DOA}_{\mathrm{it}}+\beta_{2} \mathrm{SIZE}_{\mathrm{it}}+\beta_{3} \mathrm{ROS}_{\mathrm{it}}+\beta_{4} \text { Tobin' }_{\text {it }}+\varepsilon_{\mathrm{it}} \\
& \text { Model 2: } \text { Zeros }_{\text {it }}=\beta_{0}+\beta_{1} \text { DOA }_{i t}+\beta_{2} \text { SIZE }_{i t}+\beta_{3} \text { ROS }_{\text {it }}+\beta_{4} \text { Tobin'Q }_{\text {it }}+\varepsilon_{\text {it }}
\end{aligned}
$$

Calculation and expecting signs of variables are presented in Table 1. 
Table 1. Calculation and Expecting Sign of Variables

\begin{tabular}{|c|c|c|c|c|c|}
\hline No & Variables & $\begin{array}{c}\text { Types of } \\
\text { Variables }\end{array}$ & $\begin{array}{c}\text { Variables } \\
\text { Code }\end{array}$ & Calculating Method & $\begin{array}{c}\text { Expecting } \\
\text { Signs }\end{array}$ \\
\hline 1 & \multirow{2}{*}{$\begin{array}{c}\text { Stock } \\
\text { liquidity }\end{array}$} & Dependent & TO & $\begin{array}{l}\text { Quarter's Sales/Total } \\
\text { Quarter Shares Outstanding } \\
\text { on Average }\end{array}$ & \\
\hline 2 & & Dependent & Zeros & $\begin{array}{l}\text { Numbers of Trading Days } \\
\text { with } 0 \text { Return in Year } \\
\text { t/Total Number of Trading } \\
\text { Days in Year } t\end{array}$ & \\
\hline 3 & $\begin{array}{l}\text { Financial } \\
\text { leverage }\end{array}$ & Independent & DOA & Debt/Total Assets & $(-)$ \\
\hline 4 & Business size & Controlled & SIZE & Ln (Total Assets) & $(+)$ \\
\hline 5 & Profitability & Controlled & ROS & Earnings After Tax/Revenue & $(+)$ \\
\hline 6 & $\begin{array}{c}\text { Corporate } \\
\text { Value }\end{array}$ & Controlled & Tobin’s Q & $\begin{array}{l}\text { Tobin's } Q=(\text { Total market } \\
\text { value of equity }+ \text { Net } \\
\text { debts }) / \text { Total book value of } \\
\text { assets }\end{array}$ & $(+)$ \\
\hline
\end{tabular}

Source: Authors' establishment

The study looked at factors affecting dividend policy collected from listed companies on the Ho Chi Minh City stock market for seven years from 2011 to 2017 with 1078 observations. Estimation of regression model based on tabular data. Research methods used in the model include FEM (Fixed-effect Estimation Model) and REM (Random-effect Estimation Model). The final result will be used after the defect recovery process of the selected model.

\section{Research Results}

\subsection{Statistics describe the data}

Table 2 shows descriptive statistics results of the data used in the model. In particular, the highest level of financial leverage of listed companies was $97.68 \%$ and the lowest value was $0.06 \%$. ROS is the variable with the highest variance compared to other variables. The results also showed that the average profitability (over revenue) of the company was $1.96 \%$. The 
variables representing financial leverage have the greatest value of around 0.7 , while the smallest value is the TO variable, which is 0 , and the Zeros variable, which is 0.043 .

Table 2. Statistics Describing the Variables in the Model

\begin{tabular}{ccccc}
\hline Variables & Mean & Std. & Min & Max \\
\hline ROS & 0.019 & 2.190 & -7.519 & 2.059 \\
Tobin's Q & 1.074 & 0.573 & 0.232 & 8.504 \\
sizedt & 13.742 & 1.427 & 9.123 & 18.320 \\
DOA & 0.494 & 0.204 & 0.006 & 0.976 \\
ZEROS & 0.256 & 0.119 & 0.043 & 0.756 \\
\hline
\end{tabular}

Source: Author's computation using R software

In addition, the results show that the correlation among the variables is relatively low (Table $3)$. The purpose of examining the close correlation between independent variables and dependent variables is to eliminate factors that may lead to multi-collinearity before running the regression model. The correlation coefficient between the independent variables in the model is less than 0.8 , so it is less likely that multi-collinearity will occur. The Variance Inflation Factor (VIF) will be used to test the multidimensional phenomenon between variables.

Table 3. Correlation Matrix between Variables in the Model

\begin{tabular}{lllllll}
\hline & ROS & Tobin'sQ & Sizedt & DOA & ZEROS & TURNOVER \\
\hline ROS & 1.0000 & & & & \\
Tobin's Q & 0.0424 & 1.0000 & & & & \\
Sizedt & 0.0802 & 0.2498 & 1.0000 & & \\
DOA & 0.0259 & -0.1117 & 0.3463 & 1.0000 & \\
ZEROS & 0.0388 & -0.0686 & -0.282 & 0.0303 & 1.0000 & \\
TURNOVER & 0.0121 & 0.1007 & 0.1227 & -0.0258 & -0.4163 & 1.0000 \\
\hline
\end{tabular}


The study used the Wooldridge test to test autocorrelation in regression models and the Breusch-Paga method to test variance change. Based on the results in Table 4 the coefficient $\mathrm{P}$-value $<\alpha=0.05$. So assuming $\mathrm{H}_{0}$ is rejected. The results of the model test showed that the $\mathrm{P}$-values obtained were $0.000<\alpha(5 \%)$, which implies that $\mathrm{H}_{0}$ is not affected by thevariance change/autocorrelation phenomenon. The model is rejected with a $5 \%$ significance level.

After the regression and validation, selecting the appropriate model as FEM, the authors overcome the detected defects of the model by using Generalized Least Squares (GLS). The results are presented in Table 4 . Thus, the study results showed that all four independent variables were statistically significant at $1 \%$ significance level, in which, financial leverage and profitability have the positive relationship with low liquidity (Zeros), while the size and value of the business has the opposite relationship.

\subsubsection{Models with dependent variables are Turnover}

For the turnover dependent variable (Table 5), the Hausman test results show that P-value = $0.0000<\alpha=5 \%$, thus sufficient basis for the Fixed-effect Estimation (FEM). Through the test run method, the FE model is the best model chosen.

The model also applies the same test as above: multi-collinear testing (the VIF coefficients are less than 2 , indicating no existence of multi-collinearity) as folows:

\begin{tabular}{|c|c|c|c|c|}
\hline & DOA & ROS & Tobin'sQ & Size \\
\hline VIF & 1.13 & 1.01 & 1.07 & 1.19 \\
\hline
\end{tabular}

The variance change and the self-correlation tests showed that the P-values obtained were $0.000<\alpha(5 \%)$, which implies that $\mathrm{H}_{0}$ is not affected by variance change. Models were rejected with a 5\% significance level. Therefore, the authors correct the defect of the regression model by GLS regression. The results of the study (Table 5) showa negative relationship between the financial leverage and the liquidity of the stock, while other variables have a positive relationship with stock liquidity. 
Table 5. The Regression Results with Turnover as Dependent Variable

\begin{tabular}{cccc}
\hline & FEM & REM & GLS \\
\hline DOA & $-0.0807^{* * *}$ & $-0.0325^{* *}$ & $-0.0807^{* * *}$ \\
ROS & $0.0013^{* * *}$ & 0.0011 & $0.0013^{* * *}$ \\
TOBINQ & $0.0347^{* * *}$ & $0.0142^{* * *}$ & $0.0347^{* * *}$ \\
SIZE & $0.0262^{* * *}$ & $0.0083^{* * *}$ & $0.0262^{* * *}$ \\
cons & & -0.0777 & 1078 \\
N & 1078 & 1078 \\
R-sq & 0.1067 & 0.0391 & \\
\hline Hausman test & & chisq $=611.65$ \\
\hline Breusch-Pagan LM test & & P-value $=0.0000$ & \\
\hline Breusch-Godfrey/ & & P-value $=0.0000$ & \\
Wooldridge test & & chisq $=136.66$ \\
Breusch-Pagan test & P-value $=0.0000$ \\
\hline
\end{tabular}

$\mathrm{t}$ statistics in brackets $* \mathrm{p}<0.1, * * \mathrm{p}<0.05, * * * \mathrm{p}<0.01$

Source: Author's computation using $R$ software

\subsection{Discussion of the Research Results}

From the two models of research that have been tested, the authors elaborate some discussions:

- Capital structure factor (represented by financial leverage - DOA): DOA has positive relationship with stock liquidity and negative relationship with low liquidity. This finding is consistent with conclusions by Udomsirikul et al. (2011), Lesmond et al. (2008).

- $\quad$ Profitability: ROS has positive relationship with stock liquidity and low liquidity. This result shows that the effect of ROS on liquidity of stock is unclear. Profitability on one hand increases the stock's liquidity, but on the other hand may increase the proportion of low-yielding days.

- $\quad$ Corporate value factor (Tobin's Q): The value of an enterprise is negatively correlated with low liquidity and positively correlated with liquidity. This is also the result of Allayannis \& Weston (2001).

- $\quad$ Size: The size of the business has a negative relationship with low liquidity and positive relationship with liquidity. This result is consistent with study by Wasfi A. Al Salamat (2016) and Sedeaq Nassar (2016). 


\section{Conclusion}

The study examined the impact of capital structure on the liquidity of stocks listed on the Ho Chi Minh Stock Exchange using controlled variables including size, corporate value and profitability. The results show that the capital structure has negative impact on the liquidity of stocks, while the profitability, size and corporate value have a positive relationship with stock liquidity. From the results of the study, the authors propose some of the following recommendations:

Firstly, the capital structure has negative impact on the liquidity of the stock, which implies that the increased debt ratio will reduce liquidity and increase numbers of low-yielding transactions. Therefore, businesses need to pay attention to the use of financial leverage, focusing on the source of equity capital.

Secondly, profitability, although has a positive relationship with liquidity, also has the same relationship with the low liquidity. For Vietnam's stock market, this is a phenomenon that can be explained by the fact that investors sometimes make decisions not based entirely on the profitability of the business. Investment decisions can be based on non-financial information on the market.

Thirdly, the research results show that the higher the size and value of the business, the greater the liquidity of the stock and the lower non-profitable transactions. Therefore, for investors, those are two indicators that can be considered when making decisions to select priority stocks with high liquidity in the market.

\section{References}

Amihud, Y, (2002). Illiquidity and stock returns: Cross-section and time-series. Journal of Financial Markets, 5(1), 31-56. https://doi.org/10.1016/S1386-4181(01)00024-6

Albert S. Kyle (1985). Continuous Auctions and Insider Trading. Econometrica, 53(6), 1315-1335. https://doi.org/10.2307/1913210

Allayannis, G., \& Weston, J. P. (2001). The use of foreign currency derivatives and firm market value.The review of financial studies, 14(1), 243-276. https://doi.org/10.1093/rfs/14.1.243

Đặng Thị Phương (2012). Tính thanh khoản cổ phiếu và cấu trúc vốn của các công ty niêm yết trên sở giao dịch chứng khoán Thành Phố Hồ Chí Minh. Luận văn thạc sĩ kinh tế trườngđại học kinh tế Thành Phố Hồ Chí Minh.

Frieder, L. and R. Martell, 2006. On capital structure and the liquidity of a firm's stock. Working paper, Purdue University. http://dx.doi.org/10.2139/ssrn.880421

Hansen, S., \& SungSuk, K. (2013). Influence of Stock Liquidity to Firm Value in Indonesian Stock Market. The 2013 IBEA, International Conference on Business, Economics, and Accounting, 20-23 March 2013, Bangkok - Thailand. 
Jensen, M. C. (1986). Agency costs of free cash flow, corporate finance, and takeovers. The American economic review, 76(2), 323-329. http://dx.doi.org/10.2139/ssrn.99580

Jensen, M. C., \& Meckling, W. H. (1976). Theory of the firm: Managerial behavior, agency costs and ownership structure. Journal of financial economics, 3(4), 305-360. https://doi.org/10.1016/0304-405X(76)90026-X

Lê Đạt Chí \& Hoàng Thị Phương Thảo (2015). Tác động của khủng hoảng tài chính toàn cầu lên thanh khoản của thị trường chứng khoán Việt Nam. Phát Triển \& Hội Nhập, 26(36), 53-59.

Lesmond, D, A., \& Ogden, J, P., Trzcinka, C, A, (1999). A new estimate of transaction costs. Review of financial studies, 12(5), 1113-1141. https://doi.org/10.1093/rfs/12.5.1113

Lesmond, D. A., O`Connor, P. F., \& Senbet, L. W. (2008). Capital structure and equity liquidity. Working paper, Tulane University. http://dx.doi.org/10.2139/ssrn.1107660

Modigliani, F., \& Miller, M. H. (1958). The cost of capital, corporation finance and the theory of investment. The American economic review, 48(3), 261-297.

Modigliani, F., \& Miller, M. H. (1963). Corporate income taxes and the cost of capital: a correction. The American economic review, 53(3), 433-443.

Myers, S. C., \& Majluf, N. S. (1984). Corporate financing and investment decisions when firms have information that investors do not have. Journal of financial economics, 13(2), 187-221. https://doi.org/10.1016/0304-405X(84)90023-0

RasaNorvaišienė và JurgitaStankevičienė (2014). Impact of Companies' Internal Factors on Stock Liquidity in Baltic Markets. Social and Behavioral Sciences, 156(2014), 543-547. https://doi.org/10.1016/j.sbspro.2014.11.237

Robert F. Stambaugh, Luboš Pástor (2002). Liquidity risk and expected stock returns. Journal of Political Economy, 111(3), 642-685. http://doi.org/10.1086/374184

Roll, R. (1984). A simple implicit measure of the effective bid-ask spread in an efficient market. The Journal of finance, 39(4), 1127-1139. https://doi.org/10.1111/j.1540-6261.1984.tb03897.x

Sedeaq Nassar (2016). Investigate the Factors Affecting Share Liquidity: Evidence from Istanbul Stock Exchange (ISE). Research Journal of Finance and Accounting, 7(6), 71-77.

Trang Nguyen, Huu Nhan Duong, Harminder Singh (2016). Stock Market Liquidity and Firm Value: An Empirical Examination of the Australian Market. International Review of Finance, 16(4), 639-646. http://dx.doi.org/10.1111/irfi.12082

Udomsirikul P., Seksak J. \& Pomsil J. (2010). Liquidity and Capital Structure: The Case of Thailand. Journal of Multinational Financial Management, 21(2), 106-117. http://dx.doi.org/10.1016/j.mulfin.2010.12.008 


\section{Macrothink}

Asian Journal of Finance \& Accounting ISSN 1946-052X 2018, Vol. 10, No. 2

Võ Xuân Vinh, Trần Thị Yến Duyên (2015). Thanh khoản cổ phiếu và cấu trúc vốn DN: nghiên cứu thực nghiệm trên thị trường chứng khoán Việt Nam. Tạp chíNghiên cứu kinh tế, số 443-T4/2015, 33-42.

Wasfi A. Al Salamat (2016). Macroeconomics, Firm-Specific Factors and Stock Liquidity: An Empirical Evidence from Jordan. International Journal of Financial Research, 7(5), 110-123. http://dx.doi.org/10.5430/ijfr.v7n5p110 